\title{
ANTARCTIC VIGNETTES VIII: UNSUNG HEROES - RESEARCHING THE CREW OF THE S.Y. AURORA 1911-1914
}

\author{
by H.J.G. Dartnall
}

(with six plates and one table)

\begin{abstract}
Dartnall, H.J.G. 2014 (19:xii): Antarctic vignettes VIII: Unsung heroes — researching the crew of the S.Y. Aurora 1911-1914. Papers and Proceedings of the Royal Society of Tasmania 148: 11-15. https://doi.org/10.26749/rstpp.148.11 ISSN 0080-4703.

Department of Biological Sciences, Macquarie University, New South Wales 2109, Australia. Email: herbdartnall@pip.com.au
\end{abstract}

The Steam Yacht Aurora made three voyages to the Antarctic and two to the sub-Antarctic during the Australasian Antarctic Expedition (AAE) 1911-1914. All told, 56 men served as members of the crew on these voyages. Most served on one or two voyages only, with just five men (four officers and one seaman) serving on all five. While the officers are reasonably well documented many of the seamen remain unknown though recent research has uncovered details of some of these unsung heroes of the AAE.

Key Words: crew, S.Y. Aurora, Australasian Antarctic Expedition

\section{INTRODUCTION AND DISCUSSION}

The men who comprised the crew of the S.Y. Aurora during the Australasian Antarctic Expedition (AAE) are probably the least well-known English-speaking ship's company of the heroic era of Antarctic exploration. There are several reasons for this; first, complete crew lists have only recently been published (FOM 2003, Riffenburgh 2011, Dartnall 2014); second, there was a rapid turnover of the crew who were a cosmopolitan mix of merchant seamen and, in many cases, we do not know where they came from; third, Aurora made five voyages into the Antarctic - more than any other expedition; and fourth, poor attention to paperwork at the time has led to some mistaken assumptions, not helped by the fact it all took place more than 100 years ago.

In The Home of the Blizzard the ship's company is reported as consisting of 24 men - five officers and 19 men (Mawson 1915), while Captain John King Davis, in his book With the Aurora in the Antarctic, states that the crew of the Aurora normally numbered 25 and proceeds to name 18 (Davis 1919). These figures do not tell the full story for while it is true that the crew at any time numbered in the low twenties, a total of 105 men can legitimately claim to have served on Aurora during the AAE (24 AAE, Riffenburgh 2011). Forty-nine of these men may be discounted as they did not go south. They were involved in bringing the Aurora to Australia from England and were discharged, or ran away on the way to, or in, Hobart. Or they either served briefly at the end of the expedition or when she was laid-up in Hobart for six months in 1913, or was travelling between Australian ports. This leaves 56 officers and men who served aboard Aurora on one or more of the three Antarctic and two sub-Antarctic cruises.

The crews of the five voyages are listed in table 1 . From this table it is apparent that only five men - four officers (John King Davis, Percy Gray, Clarence Petersen de la Motte and Frederick Gillies) and one Able Seaman (Oswald McNeice) - took part in every voyage.

At that time ship's officers and crew of Antarctic Expeditions were eligible to receive the King's Polar Medal in bronze; but the case had just been made for those sailors on Scott's Last Expedition, the British Antarctic Expedition (BAE) of 1910-1913, who took part in two or all three of the voyages south to the Antarctic, to receive the medal in silver. The more senior award had previously only been given to men who had wintered (Poulsom \& Myres 2000). Scott's men who made only one voyage south received a bronze Polar Medal (Poulsom \& Myres 2000).

Douglas Mawson similarly argued for the AAE crew, noting that Aurora's crew working under constantly changing ice and weather conditions experienced a harsher time than some of the winterers. Mawson's argument was accepted by the Polar Medal awards committee of the British Admiralty and silver Polar Medals were awarded to the five men who took part in every voyage south (listed above) as well as two First Officers - Frank Douglas Fletcher and John Hamilton Blair. Inexplicably no bronze medals were issued, and E.L. Adams, Harry Corner, James Forbes, Bernard McGrath, W. Maxfield, Norman Toutcher and C. (Gus) Williams, all of whom had been specially commended by Captain Davis for their work (176 AAE), together with the rest of the crew, received nothing.

The Captain's wages book (24 AAE) is the primary source for researching the crew of Aurora; but it is a working document and contains some errors so care must be taken when using it. Men with a common family name and just a single initial are always going to be difficult to trace. For example, we do not know if the G. Taylor who served as an Able Seaman on the Second Antarctic Voyage was George, Guy, Gerald, Garth or Graeme/Graham Taylor (or whatever) nor indeed where he came from. Consequently, without any other clues we are unlikely to find out more about him. There was another Taylor on the crew - G.R. Taylor in the Captain's wages book - who served as a stoker/ fireman on the second sub-Antarctic cruise and the second Antarctic voyage. With two given initials there is always a bit more hope of success and, indeed, I was confidently researching a George Reay Taylor, a Gateshead man born in 1888 who at the end of the First World War was serving as a second mate and in possession of a Master's ticket issued 
TABLE 1 - The crew of the S.Y. Aurora 1911-1914

\begin{tabular}{|c|c|c|c|c|c|}
\hline Voyage & 1st Antarctic & 1st sub-Antarctic & 2nd sub-Antarctic & 2nd Antarctic & 3rd Antarctic \\
\hline Master & J. K. Davis & J. K. Davis & J. K. Davis & J. K. Davis & J. K. Davis \\
\hline 1st Mate & N. C. Toutcher & F. D. Fletcher & F. D. Fletcher & F. D. Fletcher & J.H. Blair \\
\hline 2nd Mate & P. Gray & P. Gray & P. Gray & P. Gray & P. Gray \\
\hline 3rd Mate & C. P. de la Motte & C. P. de la Motte & C. P. de la Motte & C. P. de la Motte & C. P. de la Motte \\
\hline Chief Engineer & F. J. Gillies & F. J. Gillies & F. J. Gillies & F. J. Gillies & F. J. Gillies \\
\hline 2nd Engineer & H. Corner & H. Corner & A. Maxfield & A. Maxfield & M. Fritze \\
\hline 3rd Engineer & P. McArthur & & & & \\
\hline Cook & J. H. Rust ${ }^{1}$, A. Fifoot, & J. Saliba & S.C. Dobbs & S.C. Dobbs & L. T. Kyme \\
\hline Chief Steward & T. P. McMahon & O.F. Royall & & & C. Williams \\
\hline 2nd Steward & L. Pettit & D Whittle & C. Williams & $\begin{array}{l}\text { C. Williams, } \\
\text { S.E. Gibbon }\end{array}$ & H. V. Goddard \\
\hline Sailmaker & J. Forbes & J. Forbes & J. Forbes & J. Forbes & \\
\hline Donkeyman & & H. Haugan & & & A. Beverley \\
\hline Boatswain & D. T. Peers & E. L. Adams & E. L. Adams & E. L. Adams & J. Doherty \\
\hline Able Seaman & $\begin{array}{l}\text { E. L. Adams } \\
\text { F. W. Desmond } \\
\text { L. K. Joss } \\
\text { B. L. McGrath } \\
\text { O. W. McNeice } \\
\text { A. Schroeder } \\
\text { H. Wigzell }\end{array}$ & $\begin{array}{l}\text { J. Doherty } \\
\text { C. J. Hackworth } \\
\text { B. C. Lincoln } \\
\text { B.L. McGrath } \\
\text { O. W. McNeice } \\
\text { A. Schroeder } \\
\text { L. Vinji }\end{array}$ & $\begin{array}{l}\text { R. Bradley } \\
\text { J. Doherty } \\
\text { C. J. Hackworth } \\
\text { B. C. Lincoln } \\
\text { O. W. McNeice } \\
\text { A. Schroeder } \\
\text { L. Vinji }\end{array}$ & $\begin{array}{l}\text { R. Bradley } \\
\text { J. Doherty } \\
\text { C. J. Hackworth } \\
\text { B. C. Lincoln } \\
\text { O. W. McNeice } \\
\text { A. Schroeder } \\
\text { G. Taylor } \\
\text { L. Vinji }\end{array}$ & $\begin{array}{l}\text { M. Foley } \\
\text { J. Hansen } \\
\text { T. R. A. Liddiard } \\
\text { J. G. Mahr } \\
\text { O. W. McNeice } \\
\text { J. Offin }\end{array}$ \\
\hline Stoker & $\begin{array}{l}\text { H Coombe } \\
\text { G. Crossley } \\
\text { E. Dodds }\end{array}$ & $\begin{array}{l}\text { A. Kohler } \\
\text { A. Thompson }\end{array}$ & $\begin{array}{l}\text { A. Kohler } \\
\text { S. G. R. Taylor } \\
\text { A. Thompson }\end{array}$ & $\begin{array}{l}\text { A. Kohler } \\
\text { S. G. R. Taylor } \\
\text { A. Thompson }\end{array}$ & $\begin{array}{l}\text { E. Anderson } \\
\text { J. Blake } \\
\text { J. Mort }\end{array}$ \\
\hline
\end{tabular}

in New South Wales. True it would have been a rapid promotion from stoker in just a few years but promotional opportunities are greater in wartime! I was excited by the possibility that Gordon Reay Taylor was the Aurora's man but would have been completely wrong when the family of Stanley Gordon Roberts Taylor (pl. 1) posted his Antarctic diary online (Gale 2011). In my defence there is no $S$ for Stanley in the Captain's wages book but it does illustrate how easy it is to be led astray. Other clerical errors we know of include Sydney Clayton Dobbs who is recorded in the Captain's wages logbook as C.C. Dobbs. Sydney Clayton Dobbs applied for membership of the Antarctic Club in the 1950s on the strength of his service aboard Aurora.

While men with common names can prove to be difficult to trace the converse is true of men with unusual names and it only took two phone calls to contact the family of Cedric James Hackworth (pl. 2), who was listed as H. Hackworth in the Captain's wages book, and only one more to find the son of Laurence Thomas Kyme, cook, who was noted in the wages book as L.F. Kyme. These spelling inaccuracies are worrying and bring into question many of the other listings in the Captain's wages log. For example, do we have the correct spelling for J. G. Mahr or A. Schroeder and is the stoker on the third Antarctic voyage Enoch Anderson or Andersen? Sadly for 23 of the

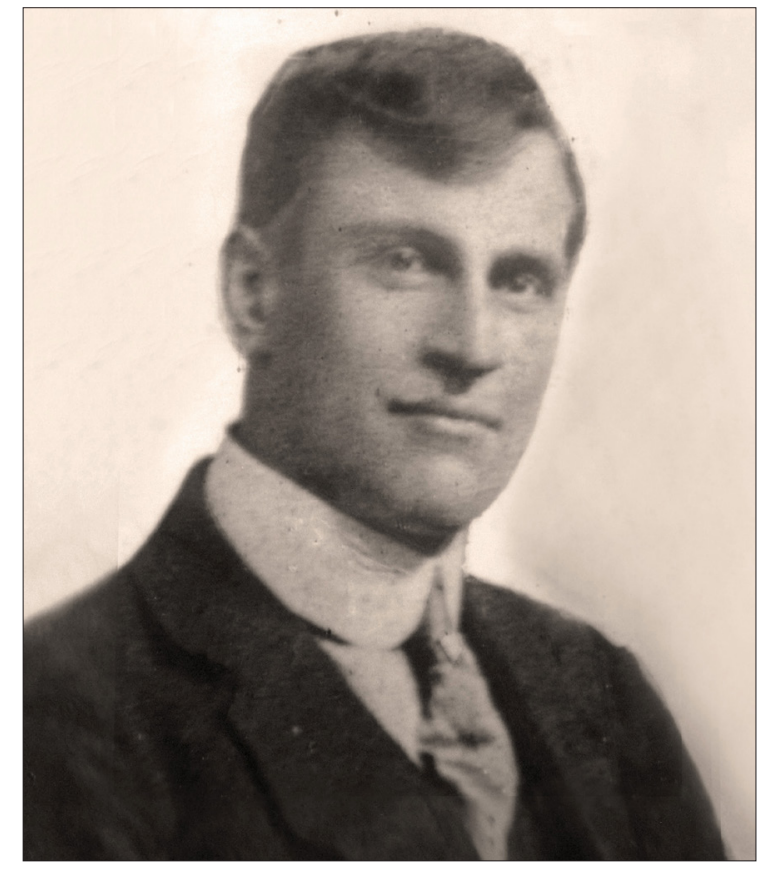

PLATE 1 - Stanley Gordon Roberts Taylor, fireman on the second sub-Antarctic cruise and second Antarctic voyage. A large, powerful Australian whose service on board the Aurora only became apparent when his family posted his Antarctic diary online in 2011. Photo source: Taylor family. 

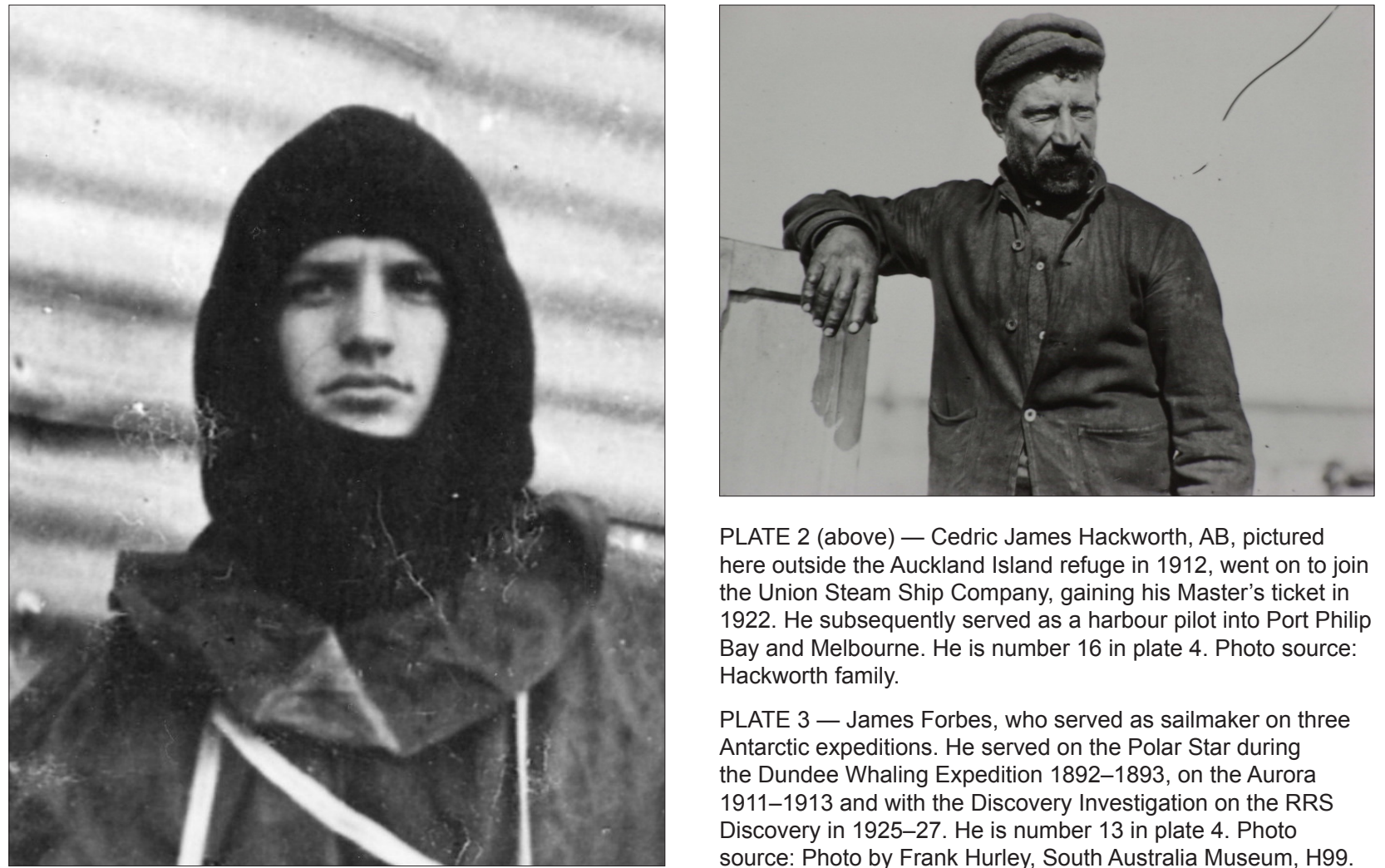

PLATE 2 (above) - Cedric James Hackworth, AB, pictured here outside the Auckland Island refuge in 1912, went on to join the Union Steam Ship Company, gaining his Master's ticket in 1922. He subsequently served as a harbour pilot into Port Philip Bay and Melbourne. He is number 16 in plate 4. Photo source: Hackworth family.

PLATE 3 - James Forbes, who served as sailmaker on three Antarctic expeditions. He served on the Polar Star during the Dundee Whaling Expedition 1892-1893, on the Aurora 1911-1913 and with the Discovery Investigation on the RRS Discovery in 1925-27. He is number 13 in plate 4. Photo source: Photo by Frank Hurley, South Australia Museum, H99.

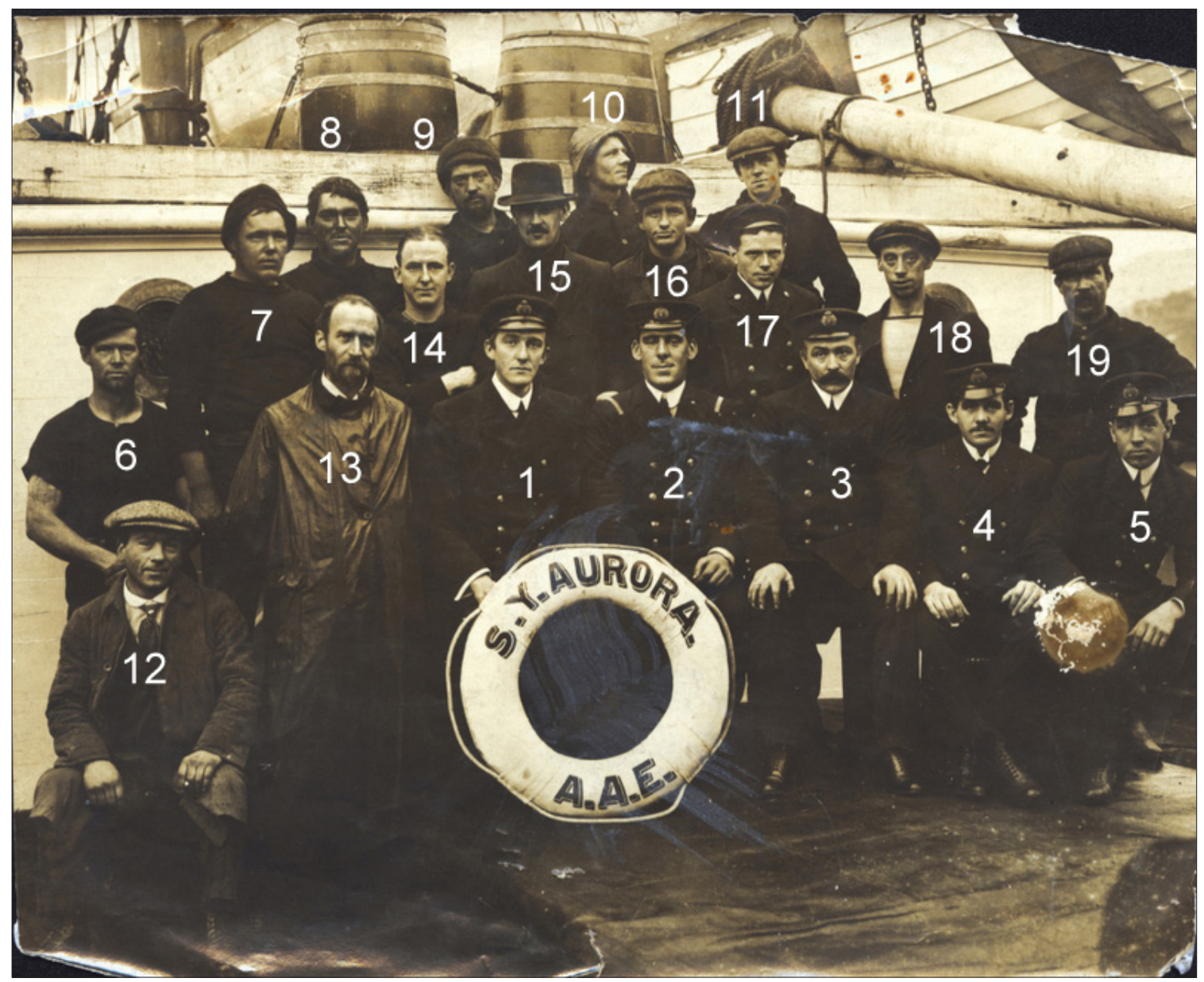

PLATE 4 - The crew of the Aurora - photograph taken by Les Hingo in Lyttelton sometime in late July/early August 1912. For identification of some of the numbered officers and men see text. Photo source: Australian Antarctic Division, The Crew at Lyttelton. 


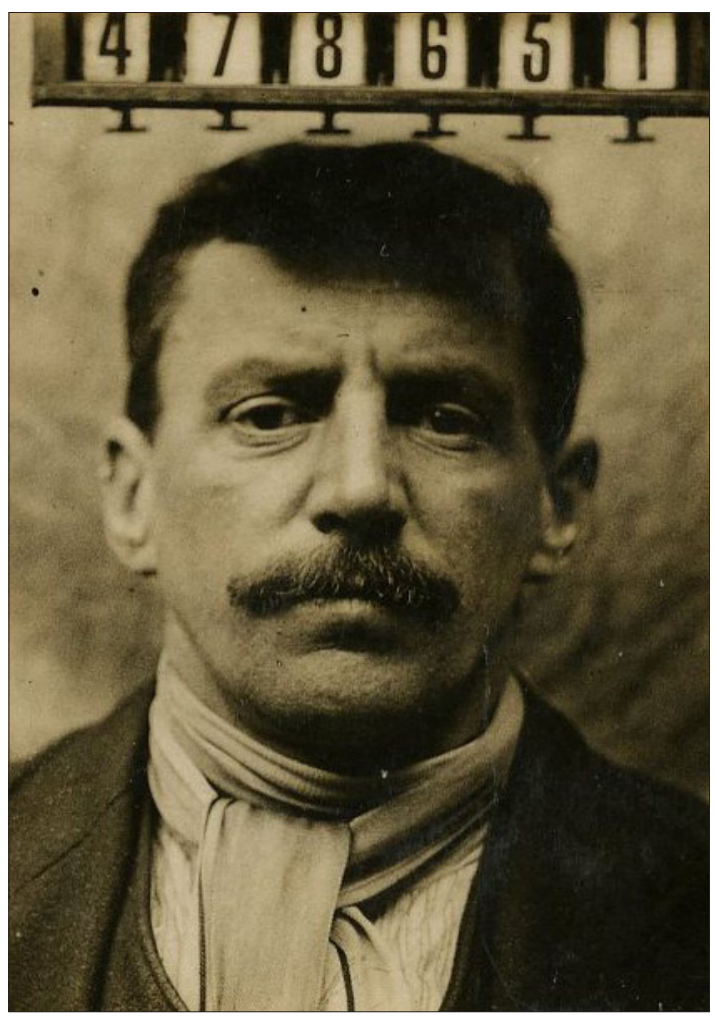

PLATE 5 - Albert Dawson, fireman on the first sub-Antarctic cruise in 1912. He was born in Salford on 30 August 1884 and saw service in the Merchant Navy during WW1. He is number 19 in plate 4. Photo source: Southampton City Council Archives CR10 478651.

crew we have nothing more than a name against their role on board (Dartnall 2014).

Photographic images can be another useful source for the researcher. However, good identified photographs of the crew are rare and few are of the quality of the Frank Hurley photo (pl. 3) in which James Forbes is identified just as the sailmaker. As there was only one sailmaker aboard the Aurora during the AAE this photo must be of James Forbes (table 1) and confirmed by other named photographs (Dartnall 2008). James Forbes, who was born in Dundee in 1871, was described as 5'4" tall with blue eyes, dark hair and a fresh complexion. With service on three Antarctic expeditions it is disappointing that nothing further is known about him but illustrates just how difficult it is to find out much about these men 100 years after the voyages.

In none of the photos in the Coombe Collection (State Library of New South Wales) of the crew taken on Macquarie Island is anyone identified. They show men well wrapped up against the cold and often sporting beards and moustaches which are not of much help for spotting distinctive features. There is one particularly good crew photo in the Australian Antarctic Division's archives - taken at Lyttelton at the end of the First sub-Antarctic cruise (pl. 4). This was taken by Les Hingo, a professional photographer, and shows 19 of the crew of 22. While the names of the five officers seated at the front and wearing peaked hats and collars and ties - are known, only four of the men are identifiable. In this photograph the lifebuoy is supported by Second Officer Percy Gray (number 1 in pl. 4). On his left is First

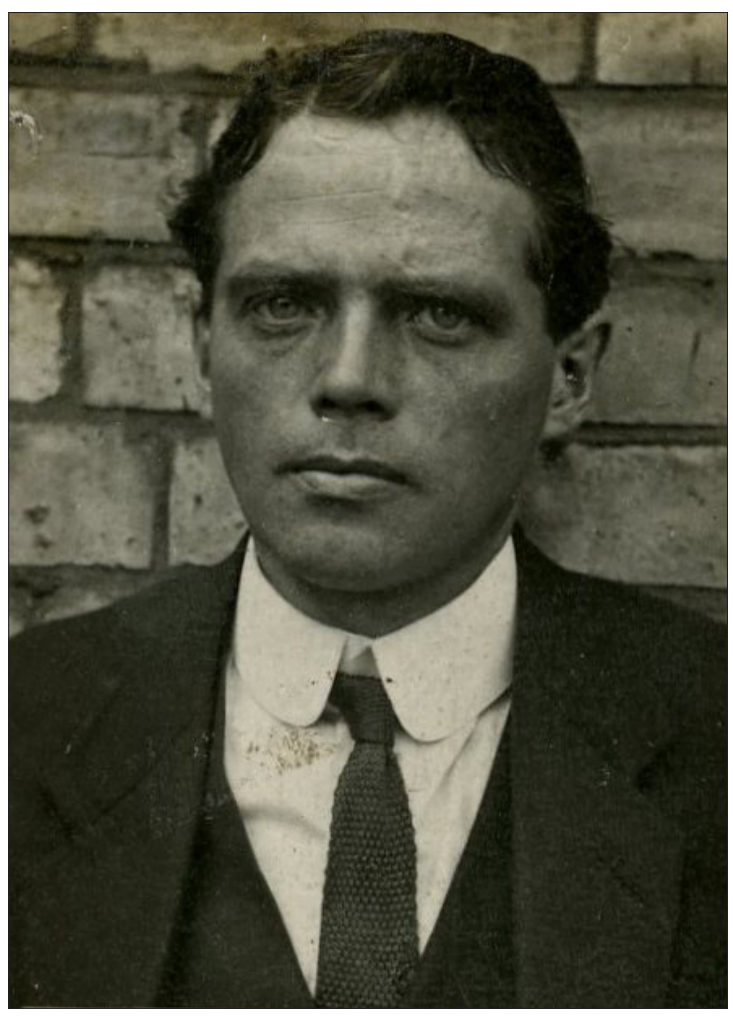

PLATE 6 - Oliver Francis Royall, Chief Steward on the first sub-Antarctic cruise in 1912. Born in Southampton, England, on 31 May 1883, he married and settled in Australia and died in Sydney in 1949. He is number 17 in plate 4. Photo source: Southampton City Council Archives CR10 853323.

Officer Frank Douglas Fletcher (number 2), then Chief Engineer Frederick Gillies is number 3, Second Engineer Harry Corner is number 4 and number 5 is Third Officer Clarence Peterson de la Motte. Of the rest I believe number 13 is the sailmaker James Forbes, number 16 is able seaman Cedric James Hackworth, number 17 is the steward Oliver Francis Royall and number 19 is fireman Albert Dawson.

Merchant Seamen's records, where they exist, are widely scattered (The National Archives, Kew, UK; Southampton City Council Archives; University of Newfoundland) and difficult to trace and interpret (see Watts \& Watts 1991 for a guide). United Kingdom seamen carried Board of Trade identity cards complete with a head and shoulders photograph and details of when and where they were born (BT 348, 349, 350). Southampton City Council Archives maintains copies of these identity cards. An opportunistic cross-check yielded six hits including two seamen (pls 5 \& 6) who served on the First sub-Antarctic cruise and both of these men, Dawson and Royall, can be identified in the crew photograph (pl. 4).

Not all seamen want to be found. It was not uncommon for young men to run away to sea, and for those with a dubious past to sign-on using an alias. At least one man served on Aurora under an alias but there is nothing suspicious in this case - Leon François William Pittet anglicised his name to Leonard Pettit - not a difficult one to fathom, but are there others?

One man, we know, did not want to be found, though this was long after the expedition had returned. Duncan Taylor 
Peers, the boatswain on the First Antarctic Voyage, was dismissed after he gave an interview to The Sun newspaper (Riffenburgh 2011) criticising Captain John King Davis and alleging panic, poor seamanship and damage when the ship touched a submerged rock in Caroline Cove, Macquarie Island, in 1911. In 1930 Duncan Peers' second wife placed advertisements in the personal columns of The Mercury (a Tasmanian newspaper) seeking his whereabouts (The Mercury 1930). Presumably she had some inkling that he was there, but I don't believe she ever found him then so what chance do we have more than 80 years later?

Soon after the expedition ended, the First World War was declared and many members saw active service. Harry Corner, Albert Dawson (pl. 5), Sydney Clayton Dobbs, Leslie Keith George Joss, Joseph Offin and Oliver Francis Royall (pl. 6) served in the Merchant Navy and were awarded the British War Medal and the Mercantile Marine War Medal (BT 351).

Many other crew members joined the Australian Army (NAA B2455) and their attestation papers occasionally contain such additional information as "went to the south pole with Douglas Mawson" as well as giving details of their height, colour of hair and eyes and where tattooed. Among the men who volunteered was Abraham Fifoot, cook, who joined Aurora at Macquarie Island; he who knocked five years off his true age of 49 to enlist in 1915 . Others who enlisted include Laurence Kyme and Thomas Percival McMahon. Herbert Victor Goddard (Quilty \& Goddard 2004) received a gun-shot wound to the buttocks, and Cedric James Hackworth was wounded in the ankle. Harry Wigzell became a prisoner of war. Five of the crew - Harry Coombe, Frederick William Desmond, Bertrum Clive Lincoln, Leonard Pettit and David Whittle - paid the ultimate sacrifice and were killed in action (Dartnall 2014).

At least one other crew member met a violent death. Bernard Lawrence McGrath, then a gold prospector in New Guinea, was ambushed by local tribesmen and was shot and killed by arrows on 24 February 1934 (The Sunday Sun 1934).

Far too many of Aurora's crew remain unknown. It is to be hoped that more will be uncovered as the families of these men come forward and from internet advances in genealogical research. The handling of Aurora by Captain John King Davis, his officers and crew was the key to the successful prosecution of the Australasian Antarctic Expedition. What they achieved under very trying conditions in uncharted waters and without modern electronic navigational aids and weather forecasts was quite magnificent. Truly the crew members are the unsung heroes of the expedition.

\section{ACKNOWLEDGEMENTS}

This paper was presented at the Aurora Symposium in Adelaide on 26 February 2014, held to celebrate the centenary of the return of the Australasian Antarctic Expedition. My thanks to the organisers of the Symposium, especially Mark Pharaoh, Mawson Centre, South Australia. My thanks also to the families of Stanley Gordon Roberts Taylor and Cedric James Hackworth who supplied information and photographs of their forebears, and to the Australian Antarctic Division (for the crew photograph), the Mawson Centre (for the photograph of James Forbes) and the Southampton City Council Archives (for the photographs of Albert Dawson and Oliver Francis Royall).

\section{REFERENCES}

24 AAE: Captain J.K. Davis's wages book for the S.Y. Aurora. Held in the Mawson Centre, South Australia Museum, Adelaide.

176 AAE: Captain J.K. Davis letter to Sir Douglas Mawson dated 26 June 1914 re Polar Medal. Held in the Mawson Centre, South Australia Museum, Adelaide.

BT 348, 349, 350: Identity cards of merchant seamen employed between 1918 and 1941. Held in The National Archives, Kew, UK.

BT 351: Cards recording the award of the British War Medal and Mercantile Marine Medal to merchant seamen. Held in The National Archives, Kew, UK.

Dartnall, H.J.G. 2008: Antarctic Vignettes 1: Mawson's Sailmaker - James Forbes. Papers and Proceedings of the Royal Society of Tasmania. 142(2):4546.

Dartnall, H.J.G. 2014: Lost in the Mists. Australian Scholarly Publishing, Melbourne: 382pp.

Davis, J.K. 1919: With the Aurora in the Antarctic 1911-1914. Andrew Melrose Ltd, London: 183 pp.

F.O.M. 2003: Crew of the S.Y. Aurora 1911-14. Friends of Mawson Newsletter. No 3: 3-7

Gale, I. 2011: Stanley Gordon Roberts Taylor's diary of his 1912-1913 voyage to Antarctica with Sir Douglas Mawson's Australasian Antarctic Expedition. www.antarcticdiary.wordpress.com/ (accessed 20 August 2014).

Mawson, D. 1915: The Home of the Blizzard. William Heinemann, London, Vol 1: 349pp. and Vol II: 338pp.

Mercury, The 1930: advertisement in the personal column of the Mercury, dated 8 April 1930.

NAA B2455: Personal service records for the First World War. Held online at the National Archives of Australia.

Poulsom, N.W. \& Myres, J.A.L. 2000: British Polar Exploration and Research: A historical and medallic record with biographies 1818 - 1999. Savannah Publications, Forest Hill, London: 729 pp.

Quilty, P.G. \& Goddard, P.H. 2004: The lower deck on Aurora: H.V. Goddard's diary, 1913-14. Polar Record 214: 193-203.

Riffenburgh, B. 2011: Aurora; Douglas Mawson and the Australasian Antarctic Expedition 1911-1914. The Erskine Press, Norwich: 525 pp.

Sunday Sun, The 1934: Stark drama in New Guinea Wilds. Page 1. The Sunday Sun, dated 11 March 1934, Sydney.

Watts, C.T. \& Watts, M.J. 1991: My ancestor was a Merchant Seaman. The Society of Genealogists, London: $84 \mathrm{pp}$.

(accepted 3 November 2014) 
